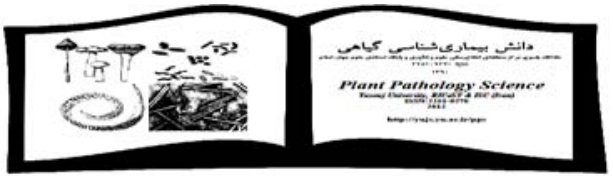

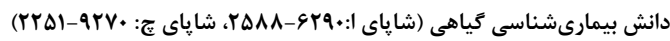

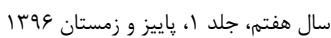

Plant Pathology Science (eISSN:2588-6290, pISSN:2251-9270) Vol. 7(1), 2018

\title{
Root Lesion Nematode Pratylenchus thornei
}

\section{EHSAN FATEMI and HABIBALLAH CHAREHGANI ${ }^{\bowtie}$}

Department of Plant Protection, College of Agriculture, Yasouj University, Yasouj, Iran

( $\triangle$ Corresponding author: h.charehgani@yu.ac.ir)

Received: 01.07.2016

Accepted: 30.07 .2017

Fatemi E. and Charehgani H. 2018. Root lesion nematode Pratylenchus thornei. Plant Pathology Science 7(1):28-39.

Abstract: Root lesion nematodes are one of the most important and fatal plant parasites. They often move between soil and host plants roots, during all stages of their life. Root lesion nematodes migrate and feed within the roots, therefore they cause necrotic lesions on the surface and throughout the cortex of infected roots. Their attack to the root can result stunting of plant root system as well as reduction in plants growth and eventually host kill. Different management methods such as the planting of resistant genotypes, crop rotation, fallow periods and use of biological control agents are successfully practiced against these nematodes. In this paper a brief discussion of economic damages, importance, taxonomy, biology and symptoms of Pratylenchus thornei attack and the most efficient management methods are presented.

Key words: Cereals, Root lesion, Nematode, Pratylenchus

\section{نماتد مولد زخم ريشه Pratylenchus thornei}

$$
\begin{aligned}
& \text { احسان فاطمى و حبيباله جارهكانى ه } \\
& \text { كروه گَياهيزشكى، دانشگاه ياسوج }
\end{aligned}
$$

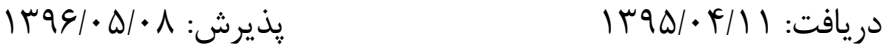

$$
\begin{aligned}
& \text { فاطمى ا. و جارهكانى ح. عqسا. نماتد مولد زخم ريشه Pratylenchus thornei. دانش بيمارىشناسى }
\end{aligned}
$$

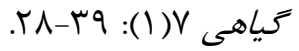

$$
\begin{aligned}
& \text { جكيده: نماتدهاى مولد زخم ريشه يكى از مهمترين و مخربترين عوامل بيمارىزاى گياهى به شمار مى آيند } \\
& \text { كه در تمام مراحل رشدى كياه بين خاك و ريشه حركت مى كنند. اين نماتـدها انغـل داخلـى مهـاجر بـوده و } \\
& \text { تغذيهى نماتد سبب يديدار شدن زخمهاى قهـوهاى نكروتيـك روى سـطح و درون كـورتكس ريشـهـى رآلـوده } \\
& \text { مى گردد و باعث از بين رفتن سيستم ريشهاى، كم شدن رشد، يزمردگى و بالاخره مرى كياه مىشود. استفاده }
\end{aligned}
$$



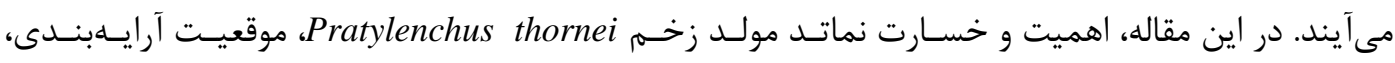

$$
\begin{aligned}
& \text { زيستشناسى، نشانهاى آلودكى و در نهايت مهرمترين روشهاى مديريت اين نماتد شرح داده شده است. } \\
& \text { وازمهاى كليدى: غلات، زخم ريشه، نماتد، Pratylenchus }
\end{aligned}
$$


نماتدهاى مولد زخم ريشه در زمرهى سه نماتد انگل گياهى بسيار مهمم و خسارتزاى محصولات زراعى

و بـاغى در سراسـر دنيـا قـرار داشـته و بعـد از نماتـد ريشـهَّرهى (Meloidogyne spp.) و نماتـد سيســى (Heterodera spp.) زخم ريشه بلهوسيلهى كَونه هاى مختلف Pratylenchus ايجاد مى شود. نماتدهاى ايسن جــس از مخـربتــرين بيمارگر ها در اغلب زياهان به شمار مى آيند (1980 Dropkin). اولين زونه اين جــس نخسـتين بـار در سـال • تحت نام MeMan) توسط ديمن (Dylenchus pratensis از جمنزارهاى هلند گزارش شد و به همـين

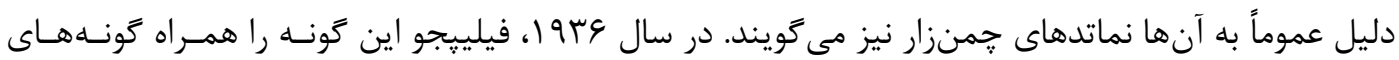
مشابه به جنس جديـدى بــ نـام Pratylenchus انتقــال داد (Davis and MacGuidwin 2000، Dalia and 2003 Bajaj). در حال حاضر بيش از • V ₹ونه از اين جنس با طيف گستردهاى از گياهان ميزبان توصيف شده است (Jones and Fosu-Nyarko 2014). دامنهى ميزبانى اين نماتـدها وسـيع بـوده و بـهـ بـيش از . ن نـوع محصول تكليه و دوليه حمله مى كنند (Nicol 2002). بهطور كلى كاهش عملكرد محصول توسط نماتد مولـد

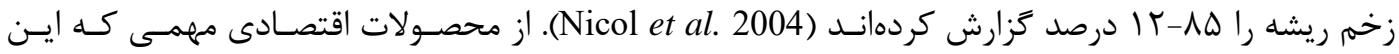
نماتدها به آن ها حمله مى كنند مى توان به غلات، حبوبات، سيبزمينى، قهوه، موز، بادام زمينـى و بسـيارى از درختان ميوه اشاره نمود (Davis and MacGuidwin 2000). بالا بودن جمعيت نماتد مولد زخم ريشه، باعـث كاهش عملكرد محصولات يكىساله در نواحى كم باران شمالغربى اقيانوس آرام در ايالات متحده آمريكا شـده است (Smiley et al. 2004). در ايران تاكنون Vratylenchus كونه ، به اسامى زير ₹زارش شدهاند (قـادرى

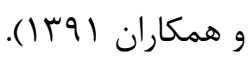

P. alleni Ferris, 1961; P. brachyurus (Godfrey, 1929) Filipjev and Schuurmans Stekhoven, 1941; P. coffeae (Zimmermann, 1898) Filipjev and Schuurmans Stekhoven, 1941; P. crenatus Loof, 1960; P. andinus Lordello, Zamith and Book, 1961; P. jaehni Inserra, Dunkan, Troccoli, Dunn, Dos Santos, Kaplan and Vovlas, 2001; P. loosi Loof, 1960; P. mediterraneus Corbett, 1983; P. neglectus (Rensch, 1924) Filipjev and Schuurmans Stekhoven, 1941; P. penetrans (Cobb, 1917) Filipjev and Schuurmans Stekhoven, 1941; P. pseudocoffeae Mizukubo, 1992; P. pseudopratensis Seinhorst, 1968; P. scribneri Steiner in Sherbakoff and Stanley, 1943; 
P. thornei Sher and Allen, 1953; P. ventroprojectus Bernard, 1984; P. vulnus Allen and Jensen, 1951; P. zeae Graham, 1951

\section{1- اهميت نماتد Pratylenchus thornei}

نماتد thornei ير اكندگى جهانى داشته و دامنهى ميزبـانى وسـيعى دارد (Whitehead 1998). ايـن نماتد تاكنون از بسيارى از كشورهاى جهان مانند ايتاليا، استراليا، يوگسلاوى سـابق، سـوريه، پِاكسـتان، هنـد، مكزيك، آلمان، مصر، زإين و آفريقـاى جنـوبى روى كَياهـان مختلـف گَزارش شـده اسـت (Fortuner 1977، Whitehead 1998 Nicol 2002 ). كاهش عملكرد محصول توسط نماتد مولد زخم ريشه در بيشتر نقاط جهان شامل ارويا، آمريكا (كلرادو و يوتا) و به خصوص اكثر منـاطق توليـد غـلات در غـرب آسـيا، آفريقـاى شـمالى، استراليا، كانادا و اسرائيل بـه اثبـات رسـيده اسـت (Smiley et al. Nicol et al. 2002، Nicol 2004، 2004 ، Nicol تورن (Thorne 1961) نماتد P. thornei را مههمترين نماتد بيماركر داخلـى ريشـهى گنــدم در يوتـاى آمريكـا

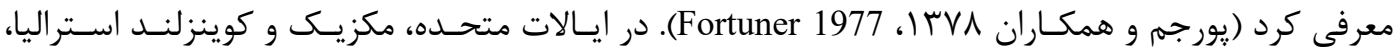
P. neglectus


محصول خصوصاً در خاك هايى كه تنش رطوبتى وجود دارد، بسيار متداول تر است. همرجنين خسارت شديدتر

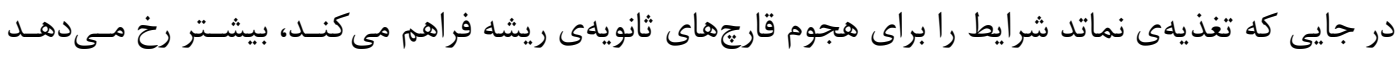

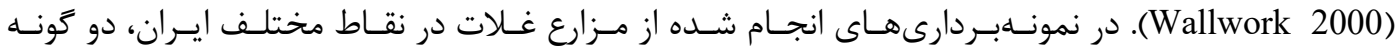
P. neglectus ور ال درصد نمونههاى خاك وجود داشـتند و ميـانگين جمعيـت نماتـد · ا تـا

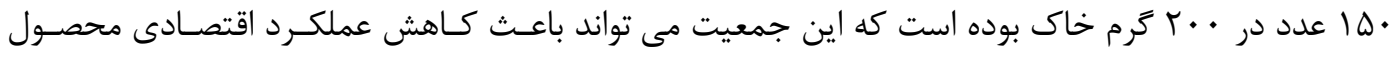
كردد (Nicol and Tanha Maafi 2004).

\section{Pratylenchus thornei موقعيت آرايهبندى و شكل شناسى}

اين گَونه براى اولين بـار توسـط شـر و آلـن (Sher and Allen 1953) از خـاك فراريشـهى جمـن در محوطهى دانشكاه كاليفرنيا آمريكا جدا گرديده است. سِيس از روى بسيارى از گياهان ديخر از جملـه يـولاف، جغندرقند، انكور، لوبيا، توتفرنكى و بادامزمينـى در ايالـت كاليفرنيـا جداسـازى و گَزارش كَرديـد. در ايـران

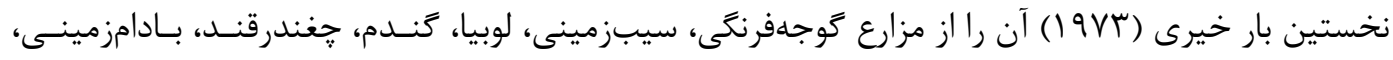






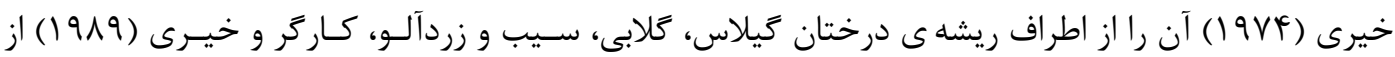
ريشهى درختان يســه در يـزد و نيكنـام و خيـرى (1991) از اطـراف ريشـهى گنــدم، ذرت و جغندرقنـد در منطقه دشت مغان جداسازى و شناسايى كردند. بررسى هاى انجام شده توسط ״ـورجم و همكـاران (I IVNA) P. neglectus P. thornei نشان داد كه در ميان گونهاى مختلف نماتد مولد زخهم ريشهى كياهان، دو گونه


مختلف غلات از بسيارى از استانها كَارش شدهاند (تنها معافى I IVVV). نماتد Pratylenchus thornei ، مطابق آرايهبندى دكرامر و هانت (Decraemer and Hunt 2013)، بـه شاخهى نماتدها (Namatoda)، رهى Chromodorea، راستهى Rhabditida، زيرراستهى Tylenchina، فـوق بالاخـانواده Thylenchomorpha، بالاخـانوادهى Thylenchoidea، خـانوادهى Pratylenchidae، زيرخـانوادهى Pratylenchinae و جنس Pratylenchus متعلق است.

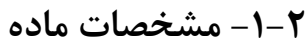

نماتدهاى كرمىشكل با بدن استوانهاى و نسبتاً قوى كه بدن بعد از تثبيت به طرف شكمى خميده يـا به شكل C باز مىشود (شكل (A-). كوتيكول داراى شيارهاى عرضى، سطوح جانبى داراى جهار شيار طـولى كه در برخى افراد شيارهاى بريده مورب در باند وسط ديده مى شود (شكل (E-E). سر نسـبتاً بلنـد، در امتـداد بدن، داراى سه حلقه، در برخى افراد يك طرف سر داراى جهار حلقه و در برخى ديكر قطعـاتى از يـك حلقـهـ ناقص در اطراف سر قرار گرفته است. شبكه كوتيكولى سر و استايلت قوى، گرههاى استايلت مشخص و اغلب كروى، سطح جلويى گرهها كمى متغير به حالت محدب، تخت يا كمى متمايل به جلو اسـت (شـكل B,C-1). غدد مرى از سمت شكمى روى روده هميوشانى دارند (شكل F-1). كيسهى ذخيرهى اسيرم كه بهسختى قابل تشخيص است، تقريباً كرد تا جهار گوش بوده و اغلب خالى از اسيرم مى باشد. كيسه عقبى رحم يك تا يـى و نيم برابر عرض بدن و فاقد سلولهاى تمايز نيافته در انتها اسـت (شـكل اDD). در اغلـب افـراد، بـدن رـس از روزنهى تناسلى به طرز محسوسى باريك مىشود. دم نيمdاستوانهاى داراى Tr تا F أ حلقه در سطح شكمى و انتهاى آن گرد يا تخت و فاقد شيار است (شكل G,H-1). فاسميدها تقريباً در وسط دم قرار دارند. 


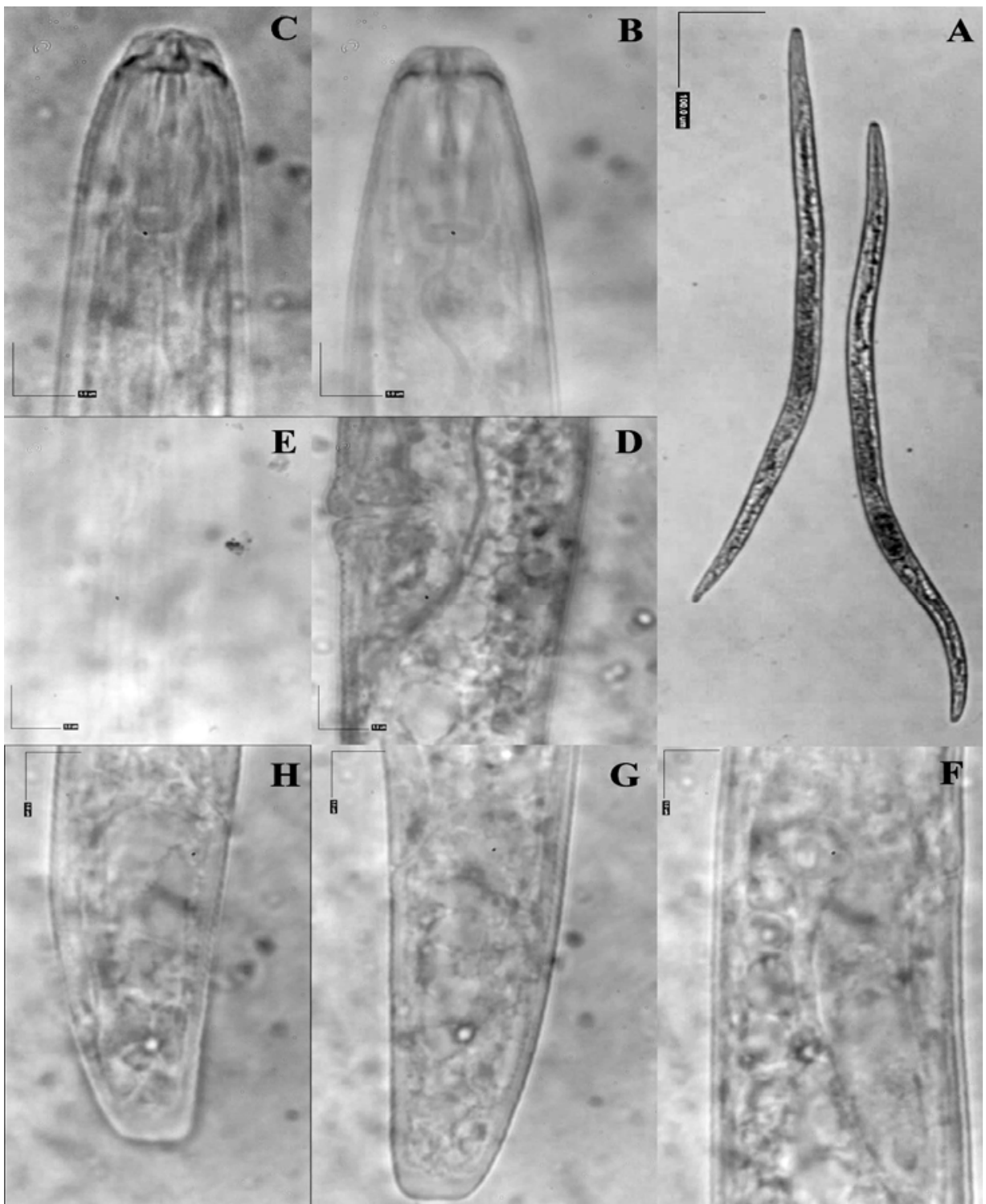

شكل ا- عكسهاى ميكروسكوٍ نـورى A A Pratylenchus thornei: شـكل كلـى بـدن، B,C: شـكل سـر و استايلت، D: روزنهى تناسلى و كيسهى عقبى رحـه، E: شـيارهاى سـطح جـانبى، F: حبـاب انتهـايى مـرى و هميوشانى شكمى، G,H: شكل انتهاى دم (اصلى)

Figure 1. Pratylenchus thornei; A: Total body, B and C: Anterior end, D: Vulva region, E: Lateral field, F: Pharyngeal region, G and H: Posterior end (Original)

ץ-ץ - نر: مشابه ماده. سر نسبتاً بلند داراى سه حلقه؛ مرى كاملاً رشد يافته. بورسـا تـا انتهــاى دم مسىرسـد. اسييكول ها از سطح شكمى خميده و گوبرناكولوم ساده است (قادرى و همكاران (9 ا ). 


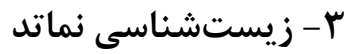

تمام مراحل رشدى نماتد از لارو سن دوم خارج شده از تخمم تا مرحلدى بلوغ بيمارىزا هستند و ممكن

است تمام مراحل زندگى آنها از تخم تا بلوغ درون ريشه تكميل شود (شكل ؟). نماتد يس از نفوذ به درون بافت، بهصورت بين سلولى و درونسلولى حركت مى كند (Walia and Bajaj 2003). نماتدها در شرايط مزرعه و آزمايشگاه بعد از كذشت شش هفته به فراوانى در داخل بافت كورتكس ريشه بهموازات مجارى آوندى در طول محور ريشه يافت مىشوند (Fortuner 1977). در نتيجهى تغذيهى آنها زخمهاى نكروزه و قهوهاىرنكى ايجاد مى كردد (Dropkin 1980). نماتد مىتواند از هر مكانى خصوصاً نوك ريشه نفوذ نمايد ( Townshend 1976 (and Anderson 1 )، اما لانسبرى (Lownsbery 1956) نشان داد كه بهترين مكان جهت نفوذ و تغذيهى نماتدهاى .Pratylenchus spp تارهاى كشندهى ريشه مىباشند (شكل ؟). هجوم اوليهى نماتد احتمالاً بلهورت تصادفى صورت مى گيرد اما نماتدهاى بعدى از طريق زخمها وارد مىشوند، احتمالاً ترشحات خارج شده از ريشههاى آسيب ديده باعث جلب بيشتر آنها مىشود (Waxter and Blake 1968، Wallace).


طول مى كشد. البته اين مدت به نوع ميزبان و درجهى حرارت خاك بستكى دارد (Dropkin 1980). درجهى حرارت و رطوبت از مهمترين عواملى هستند كه بر حيات نماتد اثر مى گذارند (Wallace 1973). بقاى با كاهش رطوبت خاك تا • له درصد و با افزايش دما، كاهش مىيابد و در • F درجهى سليسيوس نماتدها در كمتر از دو هفته از بين خواهند رفت (Fortuner 1977). در شرايط حرارت بهينه، وجود ميزبان مناسب و رطوبت كافى، ميزان توليدمثل نماتد P. thornei تا حد زيادى در سيستم ريشه افزايش مىيابد بلهورى كه باكستر و بليك (Baxter and Blake 1968) مشاهده نمودند كه تعداد اين نماتد در سيستم

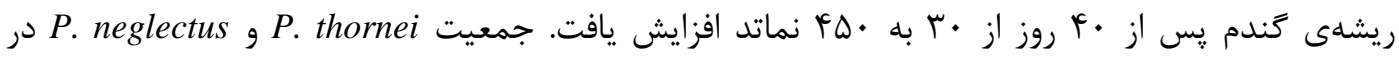
ريشههاى اوليه در مقايسه با ريشههاى طوقهاى بيشتر است در نتيجه زخمها روى ريشههاى اوليه در مقايسه با ريشههاى طوقهاى فراوانتر هستند. ريشهاى طوقهاى V-9 هفته بعد از كاشت ظاهر مىشوند، بنابراين نماتدها ابتدا ريشههاى اوليه را آلوده مى كنند. از آنجا كه ريشههاى اوليه در مقايسه با ريشههاى طوقهاى بيشتر فعال مىباشند، محل مناسبى براى هجوم نماتد محسوب مىشوند (Kempinski and Wallace 1976). 


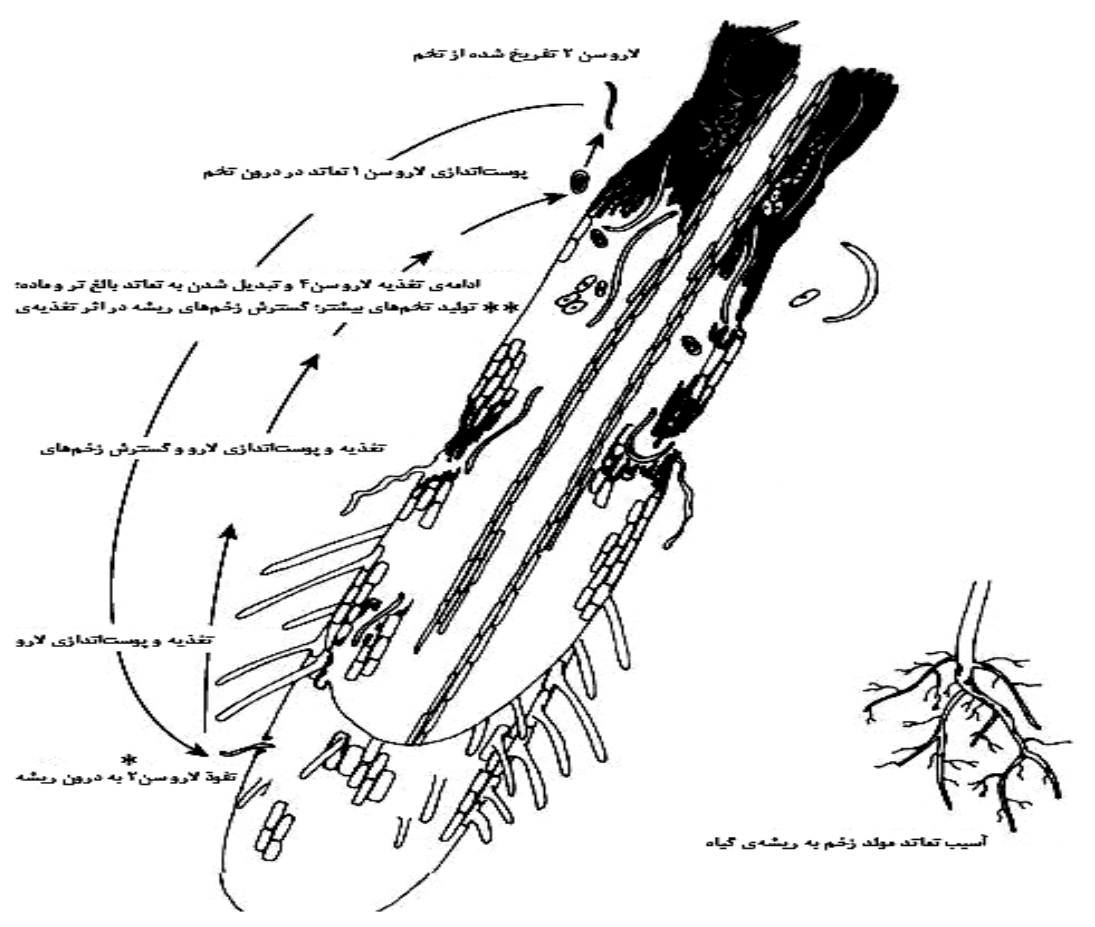

Aratylenchus thornei شكل r- جرخهى زندگى و بيمارىزايى نماتد

Figure 2. Disease cycle caused by Pratylenchus thornei

ريشههاى طوقهاى كه در طول زندگى گياه ايجاد مىشوند، امكان اداملى تغذيهى نماتد را فراهم

مى كنند و همرجنين زمانى كه ريشهاى اوليه شديداً خسارت مىبينند يا از جمعيت نماتد اشباع مى گردند، نماتدها به طرف ريشههاى طوقهاى حركت مى كنند. در واقع نماتد در ريشهاى اوليه رشد كرده، سريعاً تكثير يافته و در رقابت براى به دست آوردن مواد غذايى به ناجار به ريشههاى طوقهاى مهاجرت مىكند (Summerell et al. 2003 (Vanston 1991). بافت خاى نيز از جمله عوامل مؤثر در حركت نماتد مىباشد. P. neglectus سنگَنتر را ترجيح مىدهد (Loof 1978). در غياب ميزبان يا سخت شدن ريشهها، نماتد تا كشت محصول بعدى در خاك باقى مىماند، در اين مدت جمعيت نماتد در ينج هفتهى اول سريعاً كاهش مىيابد و يس از آن، كاهش جمعيت به كندى صورت مى گيرد (Fortuner 1977). نماتد مولد زخم غالباً با ساير عوامل بيمارىزاى خاكزى جون قارجها، باكترىها و ديگر گونههاى نماتدى، تعامل دارد. تعامل نماتد مولد زخم با 
قارجهاى گونههاى Fusarium و Verticillium كه باعث يرمردگى فلفل، بادمجان، گوجهفرنگى و سيبزمينى

مىشوند، شناخته شده است (Wack et al. 2002، Walia and Bajaj 2003 (

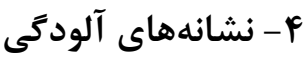

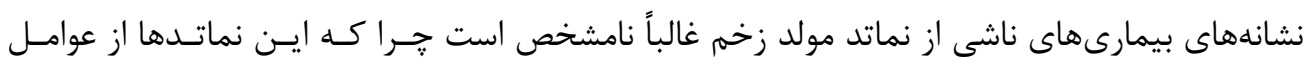

بيمارىزاى ميكروسكويى هستند كه به قسمتهاى زيرزمينى كياه (اساسـاً ريشـه) حملـه مسى كنــــ و علائهم مزرعهاى غالباً علائمى هستند كه در اثر تنش ريشهاى ايجاد شده اسـت. تنهـا بـا اسـتخراج نماتـد از خـاى و بافتهاى آلودهى گياهى مى توان بیى به وجود اين نماتد برد. در كياهان آلوده به نماتد، ريشـههـاى جـانبى در طول محور ريشه به كندى توسعه يافته در نتيجه تعداد و طول آنها كاهش مىيابد، ريشههاى مويين صـدمه مىبينند و نقاط زخمى قهوهاى رنكى بر روى ريشهها ديده مىشود. همجنين در نتيجهى تغذيهى نماتد، بافت يوستى تجزيه شده و ريشه برهنه مسىشـود (Davis and MacGuidwin 2000). نماتـد در جـذب آب و مـواد غذايى توسط كَياه اختلال ايجاد كرده و در نهايت باعث ضـف گيـاه و زوال در بـاردهى آن مسىشـود. علائسم ظاهرى در مزرعه معمولاً علائمى جون ضعف، رشد غيريكنواخت و علائم كمبود عناصر غذايى (خصوصاً كمبود Castillo et al. ( فسفر و نيتروزن كه نشانهاى آن زرد شدن برگهاى قديمى است) را از خود نشان مى خدهند 1998a a مواد غذايى است، كشاورزان با مشاهدهى اين نشانهها مبادرت به افزايش كاربرد كودهاى شيميايى مىورزنـد و بدين طريق تا حدودى خسارت ناشى از حملهى نماتد را جبران مىنمايند (فارسى و همكاران ب99 ()).



براى مبارزه با نماتد، جندين روش به صورت مديريت تلفيقى يِيشنهاد شـده اسـت. بهداشـت مزرعـهـ و مبارزه علفهاى هرز جزء اولين راهكارهاى مبارزه با كليهى آفات و بيمارىها از جمله نماتدهاسـت. اجتــاب از كاشت در خاك هاى آلوده به نماتد باعث مى شود كه جمعيت نماتدى در اين خاك ها طى زمان آيش، بـهـ زيـر سطح خسارت اقتصادى رسد. استفاده از تناوب زراعى با محصولاتى كه ميزبان اين نماتـد نمسى باشـند؛ مانـــد

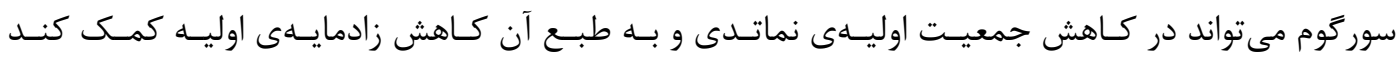
(Whish et al. 2017). استفاده از ارقام مقاوم و متحمل، يك روش مهمم براى مبـارزى اقتصـادى بـا نماتـدها 
است. ارقام مقاوم نه تنها از خسارت نماتدها جلوكيرى مى كنند، بلكه جمعيت بالقوهى نماتدها را كاهش داده و موجب حفاظت از محصولات حساس در كشتهاى بعدى مى گردند. اسـتفاده از پايـههــاى مقــاوم نيـز راه كـار

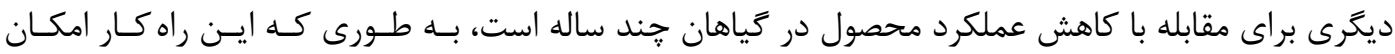
استفاده از ارقام يرمحصول ولى حساس را بر روى يايه هاى مقاوم فراهم مى كند. استفاده از روش هـاى كنتـرل زيستى براى مبارزه با نماتدها با استفاده از قارتها، باكترىها، ويروسها و نماتـدهاى شـكاركر شـيوهاى نـوين است كه در دهه هاى اخير مورد توجـهـ قـرار كرفتــه اسـت. از مزايــاى ايـن روش مبــارزهى، اسـتفاده از مـواد غيرشيميايى و حفظ محيطزيسـت را مسىــوان نـام بـرد (Siddiqui and Mahmood 1999). اسـتفاده از نـور خورشيد براى ضدعفونى كردن خاك و از بـين بـردن نماتـدها يـاـ Soil solarization يـك روش كسم هزينـه، مناسب و سودمند است (Whish et al. 2017). آبيارى كافى، عمليات خاكورزى مناسـب و كـوددهى بهينـه و

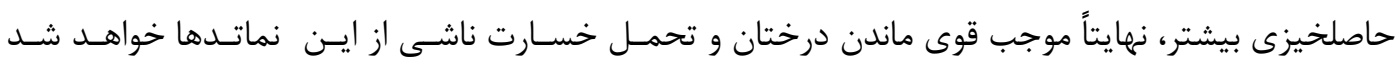
(Whish et al, 2014). بيشترين روش مورد استفاده در دهاى اخير، روش شيميايى در ضدعفونى خاك قبـل از كاشت كياه بوده است. روش شيميايى علاوه بر گرانقيمت بودن، باعث اثرهاى سوء زيستمحيطى مىشود، بنابراين استفاده از روش شيميايى تا زمانى كه كشاورز مجبور نباشد، توصيه نمى

\section{نتيجهَيرى و پييشنهاد}

جندين گونه Pratylenchus ، مانند Pratylenchus thornei ، با يراكنش جهانى، روى محصولات مهم اقتصادى در مناطق معتدل و گرمسيرى بسيار خسارتزا مىباشند. علىرغم يراكنش وسيع گونههاى مختلف نماتدهاى مولد زخم و گزارش VIV كونه از اين جنس در مناطق مختلف ايران و دامنهى ميزبانى وسيع آنها در بسيارى از محصولات زراعى و باغى، زيستشناسى و بيمارىزايى آنها به صورت بسيار محدودى در ايران مورد مطالعه قرار گرفته است. غيرفعال شدن اين نماتدها در شرايط وقوع تنشهاى محيطى و فعاليت مجدد در شرايط مساعد، يك راهكار بسيار مهرم براى بقاى آنها محسوب مىشود. نشانهاى بيمارىهاى ناشى از نماتد مولد زخم غالباً ناشناخته است جرا كه اين نماتدها از عوامل بيمارىزاى ميكروسكويى هستند كه به قسمتهاى زيرزمينى كياه (اساساً ريشه) حمله مى كنند و نشانهاى مزرعهاى غالباً نشانهايى است كه به دنبال تنش در گياه توسعه مىيابند. تنها با استخراج نماتد از خاك و بافتهاى آلودهى كَياهى مىتوان يى به 
وجود اين نماتد برد. در كياهان آلوده به نماتد، ريشههاى جانبى در طول محور ريشه به كندى توسعه يافته و در نتيجه تعداد و طول آنها كاهش مىيابد، ريشههاى مويين صدمه مىبينند و نقاط زخمى قهوهاى رنخى بر روى ريشهها ديده مىشود. همجنين در نتيجهى تغذيهى نماتد، بافت يوست ريشه تجزيه مىشود. نماتد بيماركر در جذب آب و مواد غذايى توسط كياه اختلال ايجاد كرده و در نهايت باعث ضعف گياه و زوال در باردهى آن مىشود. معمولاً گياهان نشانههايى خون ضعف، رشد غير يكنواخت و كمبود عناصر غذايى (خصوصاً كمبود فسفر و نيتروزن) را از خود نشان مىدهند. بهترين روش مبارزه با نماتدهاى مولد زخم ريشه كياهان، تلفيق روشهاى عمليات خاكورزى مناسب، آبيارى كافى، كوددهى بهينه و مبارزهى زيستى است.

\section{References}

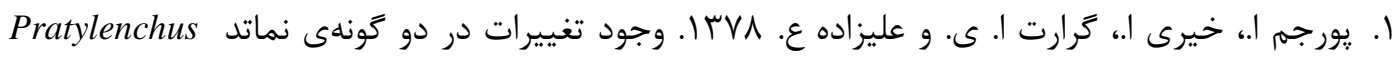
Pratylenchus neglectus و thornei

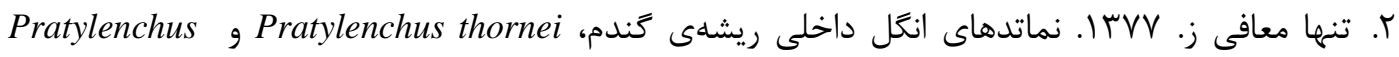
neglectus در استان كيلان. سيزدهمين كنگرهى كياهيزشكى، آموزشكدهى كشاورزى كرج، ا تا هـ

$$
\text { شهريورماه، تهران، ايران. ص } 94 .
$$

r. فارسى م.، راتجين ا.، فيشر ج. م. و وانستن و. س991. اثر نماتد مولد زخم ريشه .Pratylenchus spp بر



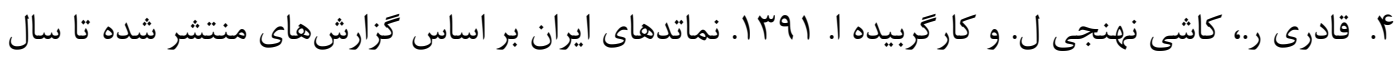

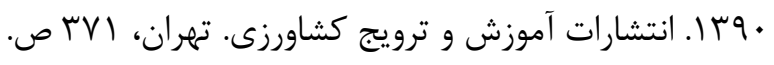

5. Back M. A., Haydock P. P. J. and Jenkinson P. 2002. Disease complexes involving plant parasitic nematodes and soilborne pathogens. Plant Pathology 51:683-697.

6. Baxter R. I. and Blake C. D. 1968. Pratylenchus thornei a cause of root necrosis in wheat. Nematologica, 14:351-361.

7. Castillo P., Mora-Rodríguez M. P., Navas-Cortés J. A. and Jiménez-Díaz R. M. 1998a. Interactions of Pratylenchus thornei and Fusarium oxysporum f. sp. ciceris on Chickpea. Phytopathology 88:828-836. 
8. Castillo P., Vovlas N. and Jimenez-Diaz R. M. 1998b. Pathogenicity and histopathology of Pratylenchus thornei populations on selected chickpea genotypes. Plant Pathology 47:370376.

9. Davis E. L. and MacGuidwin A. E. 2000. Lesion nematode disease. The Plant Health Intructor. Doi: 10. 1094/PHI-I-2000-1030-02.

10.Decraemer W. and Hunt D. J. 2013. Structure and classification. Pp. 3-39. In: R. N. Perry and M. Moens (ed.). Plant Nematoligy $2^{\text {nd }}$ Edition, CABI, USA.

11.Dropkin V. H. 1980. Introduction to plant nematology. John Weiley and Sons Inc, USA, $291 \mathrm{p}$.

12.Fortuner R. 1977. Pratylenchus thornei. C. I. H. Description of plant parasitic nematode. Common wealth Institute of Helminthology, Set7, No. 93. Commonwealth Institute of Helminthology, 103 Peter's Street, S. Albans, Herts., England, 3p.

13.Jones M. G. K. and Fosu-Nyarko J. 2014. Molecular biology of root lesion nematodes (Pratylenchus spp.) and their interaction with host plants. Annals of Applied Biology 164:163-181.

14.Jothi G., Babu R. S., Ramakrishnan S. and Rajendran G. 2004. Management of root lesion nematode, Pratylenchus delattrei in crossandra using oil cakes. Bioresource Technology 93:257-259.

15.Kempinski J. and Wallace H. R. 1976. Influence of some environmental factors on population of Pratylenchus minyus on wheat. Journal of Nematology 8:310-314.

16.Loof P. A. A. 1978. The genes Pratylenchus Filipjev, 1963 (Nematoda: Pratylenchidae): a review of its anatomy, morphology, distribution, systematics and identification. Vaxtskyddsrapporter, Jordbruk 5:1-50

17.Lownsbery B. F. 1956. Pratylenchus vulnus primary cause of the root lesion disease of walnuts. Phytopathology 46:376-379.

18. Nicol J. M. and Tanha Maafi Z. 2004. Report of cereal root pathogen soil surrey in Iran. Compiled by Iranian and CIMMYT scientists, $14 \mathrm{p}$.

19.Nicol J. M., Rivoal R. Taylor S. and Zahaieva M. 2004. Global importance of cyct (Heterodera spp.) and lesion nematodes (Pratylenchus) on cereals. Yield loss population dynamics, use of host resistance and integration of molecular tools. Nematology Monographs and Perspectives 2:1-19.

20.Nicol, J. M. 2002. Important nematode pests of cereals. Pp. 345- 366. In: B. C. Curtis (ed.). Bread wheat: improvement and production. FAO Plant Production and Protection Series, Rome, Italy. 
21. Siddiqui Z. A. and Mahmood I. 1999. Role of bacteria in the management of plant parasitic nematodes: A review. Bioresource Technology 69:167-179.

22.Smiley R., Whittaker R., Gourlie J., Easley S., Rhinhart K., Jacobsen E., Burnett A., Jackson J., Kellogg D. and Zeckman T. 2004. Lesion nematodes reduce yield in annual spring wheat. Columbia Basin Agricultural Research Center Annual Report. 1054:44-60.

23. Summerell B. A., Salleh B. and Leslie J. F. 2003. A Utilitarian approach to Fusarium identification. Plant Disease 87:117-128.

24.Townshend J. L. and Anderson R. V. 1976. Pratylenchus neglectus description of plant parasitic nematode. Commonwealth Institute of Helminthology. Set. 6, NO.82. Farnham Royal, UK: Commonwealth Agricultural Bureaux, 4p.

25.Vanston V. A. 1991. The role of fungi and root lesion nematode, P. neglectus, in damaging wheat roots in South Australia. Un Published Ph.D thesis, Waite Agricultural Research Institute, 151-156.

26. Walia R. K. and Bajaj H. K. 2003. Textbook on introductory plant nematology. Indian Council of Agricultural Research, New Delhi, 227p.

27. Wallace H. R. 1973. Nematode ecology and plant disease. Edward Arnold, London, 228p.

28. Wallwork H. 2000. Cereal root and crown diseases. Grains Research and Development Corporation, Kingston, ACT, Australia, 58p.

29. Whish J. P. M., Thompson J. P., Clewett T. G., Lawrence J. L. and Wood J. 2014. Pratylenchus thornei populations reduce water uptake in intolerant wheat cultivars. Field Crops Research 161:1-10.

30.Whish J. P. M., Thompson J. P., Clewett T. G., Wood J. and Rostad H. E. 2017. Predicting the slow decline of root lesion nematodes (Pratylenchus thornei) during host-free fallows to improve farm management decisions. European Journal of Agronomy 91:44-53

31. Whitehead A. G. 1998. Plant nematode control. CAB International, 384p. 